\title{
Pain characteristics of older residents in Iranian nursing homes
}

Mahshid Foroughan, ${ }^{1}$ Farahnaz Mohammadi Shahboulaghi, ${ }^{1}$ Zahra Jafari, ${ }^{2}$ Vahid Rashedi ${ }^{3,1}$ and Akbar Biglarian ${ }^{4}$

${ }^{1}$ Iranian Research Center on Aging, University of Social Welfare and Rehabilitation Sciences, Tehran, Islamic Republic of Iran. ${ }^{2}$ Department of Basic Sciences in Rehabilitation, School of Rehabilitation Sciences, Iran University of Medical Sciences, Tehran, Islamic Republic of Iran. ${ }^{3}$ School of Behavioral Sciences and Mental Health (Tehran Institute of Psychiatry), Iran University of Medical Sciences, Tehran, Islamic Republic of Iran. ${ }^{4}$ Department of Biostatistics, University of Social Welfare and Rehabilitation Sciences, Tehran, Islamic Republic of Iran. (Correspondence to: Mahshid Foroughan: m_foroughan@yahoo.com).

\begin{abstract}
Background: Pain is a common complaint among the aging population, particularly among the older residents of nursing homes.

Aims: The main aim of the study was to examine the pain characteristics among older residents of nursing homes in Tehran, Islamic Republic of Iran.

Methods: This was a cross-sectional study. The sample consisted of 394 older adults admitted to Tehran nursing homes. To gather the required data, Brief Pain Inventory and Abbreviated Mental Test score were used.

Results: $51 \%$ of the female and $26 \%$ of the male participants suffered from pain. Lower extremity and lower part of back were the most frequently affected. Pain interfered with general activity $(P<0.001)$, mood $(P=0.016)$, walking $(P<0.001)$, normal work $(P<0.001)$, relations with others $(P=0.043)$, sleeping $(P=0.002)$ and enjoyment of life $(P=0.019)$ of the older residents and these effects were more prominent in female sex. Factors such as age, gender and schooling were of significant relationships with pain $(P<0.001)$ and its intensity $(P<0.001)$.

Conclusions: Chronic pain is common among older residents of nursing homes and deteriorates their quality of life. This study reconfirms the previously mentioned importance of using effective pain evaluation and pain management strategies in nursing homes.

Keywords: Pain assessment, older adults, nursing home, pain management, Iran

Citation: Foroughan M; Mohammadi Shahboulaghi F; Jafari Z; Rashedi V; Biglarian A. Pain characteristics of older residents in Iranian nursing homes. East Mediterr Health J. 2019;25(3):205-212. https://doi.org/10.26719/emhj.18.045

Received: 05/11/16; accepted: 14/11/17

Copyright (c) World Health Organization (WHO) 2019. Some rights reserved. This work is available under the CC BY-NC-SA 3.0 IGO license (https:// creativecommons.org/licenses/by-nc-sa/3.0/igo).
\end{abstract}

\section{Introduction}

Pain is a common complaint among the aging population, particularly among the older residents of nursing homes (1-3); it is mostly due to the increasing prevalence of age-related disorders, such as arthritis, osteoporosis, and peripheral vascular diseases (4), which are mostly progressive. Usually the resultant pain is persisting due to the degenerative nature of these conditions. Pain can lead to mobility decline, role change, and psychological disturbance. Pain resulting from acute or chronic conditions is associated with decreases in physical and social functions, activities of daily living (ADL) and quality of life, and it is seen as a key indicator of physical limitations (5-7). Older people often do not actively report pain, perhaps because of the stigma associated with it or because of their own forbearance/stoicism (8). Undetected and untreated pain is still common among nursing home residents, and persists despite pain management quality indicators (9).

With the gains in life expectancy during the 2oth century, the number of people aged 65 and older has increased and by the middle of the 21st century, those aged 60 and above will make up $22 \%$ of the world's population (10). The increase in the aging population is accompanied by greater demand for long-term healthcare services.
Sandberg et al. reported that more than $40 \%$ of European older adults aged 65 or above will spend some time of their life in a nursing home (11). It has been estimated that $45 \%$ to $80 \%$ of nursing home residents suffer from and report persistent pain, making it one of the most commonly reported symptoms in long-term care facilities (12-14). Recent evidence in the Islamic Republic of Iran revealed that the majority of older adults reported knee and back pain (more than 50\%) and this was regardless of the chronicity, time, and the mode of reactions they aroused in the participants (15).

The aging population in the Islamic Republic of Iran has increased in the last few decades; more than six million people are aged 60 and over $(9.3 \%$ of total population) (16). Long-term care of elders is still mostly family-based and residents of nursing homes usually are the most medically and socially vulnerable. Recently, an ascending trend in the number, capacity and spread of nursing homes in the country has occurred, which is indicative of the necessity of paying more attention to them (17). However, the population using nursing home services in the Islamic Republic of Iran is at variance with their counterparts in Western societies. In Iranian culture, caring for older individuals is the duty of the family, and families are considered the main source of 
support. Iranian nursing home residents are mostly impoverished and homeless people, stricken by multiple physical and psycho-social problems, with no family members available. Such nursing homes offer help with custodial and bathing, dressing and eating, as well as skilled care given by registered nurses including medical monitoring and treatments (18).

The high prevalence of pain and its impact on older adults' lives makes it an important public health issue (19). Assessment of pain, especially in nursing homes, is often problematic (20). However, in managing pain, it is important to provide an individually tailored care for each resident, which depends considerably on careful pain assessment (21). Tse et al. advised all nurses to improve their skills in assessing and managing pain of older people in order to decrease their suffering, frailty and psychological distress (22). Therefore, improving pain assessment and management should be considered as a high priority for healthcare providers $(23,24)$. Thematic analysis by Harmon et al. identified that pain relief and care requires inclusion of the older person in the provision of care (25).

It is thought that little research has been done on pain among nursing home residents in the Islamic Republic of Iran. We found just one study by Asghari et al. which revealed that $72.8 \%$ of the residents of nursing homes in Tehran had some kind of pain and $66.7 \%$ reported persistent pain (i.e., the existence of pain every day or almost every day) (26). It seems that despite the high prevalence of pain among nursing home residents, this topic still has not been adequately explored in and somehow neglected by both clinicians and researchers. However, experience of pain could be modified by social and cultural factors (27), therefore it is necessary to look at the contexts if we intend to gain a deeper knowledge into pain characteristics of a specific population. Thus, the present study was implemented with the aim to examine the pain characteristics of older people residing in the nursing homes of Tehran.

\section{Methods}

\section{Design and participants}

In this cross-sectional study, 13 nursing homes (total 31) were approached through cluster sampling method and their residents were invited to participate in the study. To select nursing homes, Tehran was divided into five regions including north (three homes), south (two homes), east (two homes), west (three homes), and central (three homes), and part based on official socioeconomic status index. The first two nursing homes were selected from each region randomly, and if they could not fill up their share in the sample, another one randomly selected. The final sample consisted of 394 older adults out of 1500 residents of Tehran nursing homes in 2012. Mean age of the 394 participants was 74.3 (SD: 10.8) years, and $253(59.6 \%)$ were female.

Approval for the study was granted by the Human Subjects Ethics Sub-committee of the University of Social
Welfare and Rehabilitation Sciences, Deputy of Research. Participants were informed about the aim and procedure of this study, and written consent was obtained from all the participants. They were informed that they could withdraw from the study at any time and that all information related to them would remain confidential. Inclusion criteria for the participants included age being 60 years or older, ability to communicate in Persian and orientation to time and place, living in nursing homes for at least a month (decreasing the impact of stressful life event of transition to nursing home), and no significant cognitive impairment (AMTs $\geq 7$ ) (28). After selecting participants, due to the high frequency of low literacy and illiteracy among them, the study questionnaires were addressed to the participants by trained research assistants and their responses taken.

\section{Data collection}

A demographic information form was completed by the participants and included questions about age, gender and schooling. The Brief Pain Inventory (BPI) was used to gather the data; it evaluates the multidimensional nature of pain including pain sites, pain intensity and pain interference with life activities during the period of a week (29). BPI consists of three parts; first, it includes pictures representing back and front body outlines which are presented to participants to mark their area of pain on them, and sequentially numbering the different pain sites. Second, it includes four single-item measures of pain intensity: worst pain, least pain, average pain, and current pain. Each item is rated from o ("no pain") to 10 ("the worst pain I can imagine"). The average of these four items represents patients' overall pain intensity. Third, it includes seven items that assess the extent to which pain interferes with general activity, mood, walking, normal work, relations with others, sleeping, and enjoyment of life. Each item is rated on a 0-10 scale (30). The BPI is validated for use in older adults (31) and Mirzamani et al. showed that the BPI is a valid and reliable tool in the Iranian population (32).

Significant cognitive impairment among the study participants, interfering with informed consent, was evaluated using the Abbreviated Mental Test score (AMTs) - a brief 10-item survey. Each question answered correctly scored one point and a score of 7 or less suggested cognitive impairment at the time of testing. AMTs was introduced by Hodkinson in 1972 (33). It is a rapid tool for assessing cognitive function and especially useful in determining the risk of dementia in vulnerable older patients (34). This instrument has previously been validated in Iranian elderly $(35,36)$.

\section{Data analysis}

Descriptive statistical analysis of the quantitative data was conducted using the SPSS Version 16.0 (Chicago, SPSS Inc.). The Mann-Whitney U, Spearman's Rho Correlations and Chi-Square $(\chi 2)$ tests were used to measure the relationships between variables. The level of statistical significance was set at $P<0.05$. 


\section{Results}

Based on the results, 244 (62\%) had no formal education, $75(19 \%)$ were at elementary, $49(12.4 \%)$ at high school and $26(6.6 \%)$ at academic levels. Most of the subject had AMTs $=10(\mathrm{n}=137,34.8 \%)$ and the mean of AMT score was 8.75 (SD: 1.24). Figure 1 clearly shows the areas of pain among the older adults. Lower extremities on front and lower part of trunk at back (lower back) were the most frequently reported as pain sites.

The mean overall pain intensity in elders with pain was as follows: worst pain $(5.03 \pm 3.46)$, least pain (1.1 \pm 1.7), average pain $(2.9 \pm 2.3)$ and current pain $(1.68 \pm 2.5)$. Table 1 presents pain intensity in elderly nursing home residents. Mean time of pain was 57.29 months (SD: 46.76) and as Table 2 illustrates, most of the residents suffered from pain for more than 60 months $(\mathrm{n}=137$, $34.8 \%$ ). The findings also highlighted the participants applied self-care strategies in managing their pain. Most of the participants took prescribed medications $(\mathrm{n}=287$, $72.8 \%)$, used ointments $(n=62,15.7 \%)$, massage $(n=62$, $15.7 \%)$, hot pack $(\mathrm{n}=1,0.3 \%)$ and others procedures $(\mathrm{n}=8$, $2 \%$ ) to relieve their pain. $45.2 \%$ used one self-care strategy $(\mathrm{n}=178), 22.8 \%(\mathrm{n}=90)$ two strategies, and $8.9 \%(\mathrm{n}=35)$ three strategies to manage pain; 91 participants $(23.1 \%)$ reported as unspecified.

The study indicated that $51 \%$ of the female and $26 \%$ of male participants suffered from pain. Table 3 shows that pain significantly interfered with general activity, mood, walking, normal work (includes both work outside the home and housework), relations with others, sleeping, and enjoyment of life in older residents and these effects were more prominent in females. Table 4 indicates that factors such as age, gender and schooling are significantly associated with pain and its intensity.

\section{Discussion}

The present study set out to determine pain characteristics in older residents of nursing homes in the Islamic Republic of Iran. The prevalence of pain in our sample was within the range found in some previous studies (37-39). In a literature review of pain prevalence among older residents of nursing homes, 27 studies were conducted between 1990 and 2009, and Takai et al. (4) found a wide prevalence rate between $3.7 \%$ and $79.5 \%$, depending on research data sources used to detect pain. These results are consistent with those presented by Lukas et al. (3) in Services and Health for Elderly in Long TERm care (SHELTER) study, which reported pain prevalence varied significantly among countries, ranging from $19.8 \%$ in Israel to $73.0 \%$ in Finland. Our finding provides evidence that the largest proportion of this sample suffered from severe pain, and they needed more effort on behalf of the care providers in relieving pain. Moreover, the participants reported multiple sites of pain, with some similarity to previous findings $(15,40,41)$. Consistent with the findings by Lukas et al. (3,12), and Zwakhalen et al. (13), we also found that pain prevalence appears to be demonstrably higher among females than males.

This study showed that older residents, compared with younger ones, were more likely to report suffering pain. The result is in line with the study by Leong (42), yet another study found that residents with chronic pain were younger than those without pain (43), while other studies showed no significant associations between pain and the residents' age $(44,45)$. These conflicting results could be due to differences in sample size or methods used in the studies. Therefore, it seems that further studies are required to explore the subject.

The results of this investigation showed that there is a

Figure 1 Distribution of pain areas in the participants $(\mathrm{N}=394)$
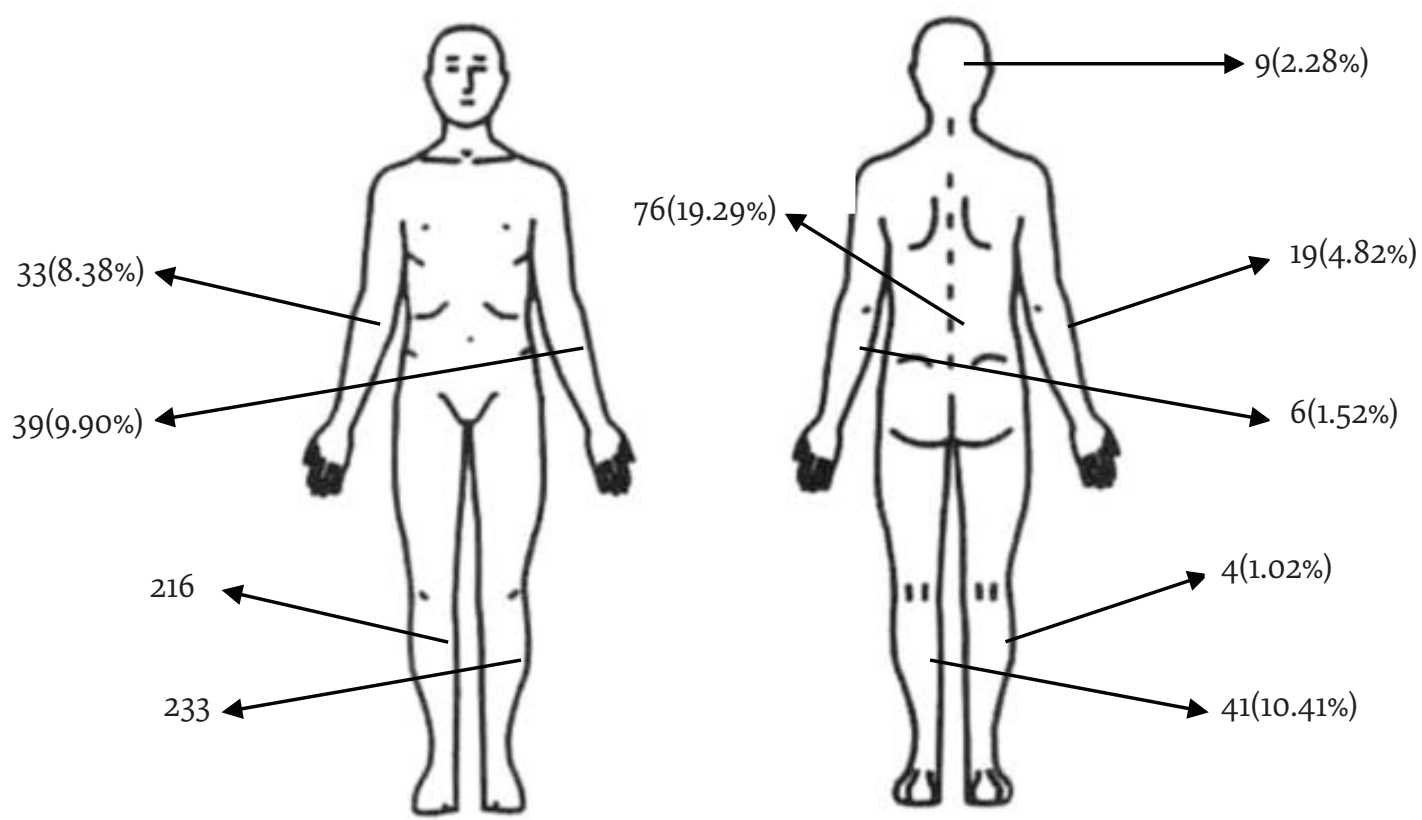


\begin{tabular}{|c|c|c|c|c|}
\hline Pain intensity & Worst pain & Least pain & Average pain & Current pain \\
\hline No pain & $86(21.8 \%)$ & $223(56.6 \%)$ & $86(21.8 \%)$ & $208(52.8 \%)$ \\
\hline 1 & $0(0.0 \%)$ & $37(9.4 \%)$ & $36(9.1 \%)$ & $38(9.6 \%)$ \\
\hline 2 & $6(1.5 \%)$ & $75(19.0 \%)$ & $70(17.8 \%)$ & $52(13.2 \%)$ \\
\hline 3 & $45(11.4 \%)$ & $42(10.7 \%)$ & $56(14.2 \%)$ & $30(7.6 \%)$ \\
\hline 4 & $16(1.4 \%)$ & $5(1.3 \%)$ & $30(7.6 \%)$ & $17(4.3 \%)$ \\
\hline 5 & $82(20.8 \%)$ & $2(0.5 \%)$ & $56(14.2 \%)$ & $15(3.8 \%)$ \\
\hline 6 & $14(3.6 \%)$ & $1(0.3 \%)$ & $45(11.4 \%)$ & $5(1.3 \%)$ \\
\hline 7 & $23(5.8 \%)$ & $4(1.0 \%)$ & $4(1.0 \%)$ & $6(1.5 \%)$ \\
\hline 8 & $46(11.7 \%)$ & $0(0.0 \%)$ & $4(1.0 \%)$ & $7(1.8 \%)$ \\
\hline 9 & $17(4.3 \%)$ & $0(0.0 \%)$ & $2(0.5 \%)$ & $5(1.3 \%)$ \\
\hline 10 & $56(14.2 \%)$ & $4(1.0 \%)$ & $4(1.0 \%)$ & $9(2.3 \%)$ \\
\hline Pain as bad as you can imagine & $3(0.8 \%)$ & $1(0.3 \%)$ & $1(0.3 \%)$ & $2(0.5 \%)$ \\
\hline
\end{tabular}

\begin{tabular}{lcc}
\hline \multicolumn{3}{l}{ Table 2 Duration of pain among the participants $(\boldsymbol{n}=\mathbf{3 9 4})$} \\
Period (months) & $\mathbf{n}$ & $\%$ \\
$\leq 12$ & 71 & 18.0 \\
$13-24$ & 40 & 10.1 \\
$25-36$ & 33 & 8.4 \\
$37-48$ & 25 & 6.3 \\
$49-60$ & 33 & 8.4 \\
$>60$ & 107 & 27.2 \\
Unspecified & 85 & 21.6 \\
\hline
\end{tabular}

significant relationship between pain and schooling, which is in line with SAGE, a large study investigating risk factors associated with low back pain in older adults living in lower/middle income countries (46), although some other studies in more high-income countries such as Spain (47) and the United States (48) had contrary results. Our findings showed that the lower extremity and lower part of back were the most frequently reported as pain sites. This finding is supported by Tse et al. (40), Mobily et al. (49) and Fries et al. (50). On the other hand, Kim et al. showed that knee pain and lower back pain are important factors affecting quality of life in middle-aged and elderly people (51). These results are consistent with the findings of our study which revealed that pain interferes with mood, sleeping, daily activities, communication with others and overall enjoyment of life. The results of Tse et al. (52), Hairi et al. (53), and William et al. (54), also, suggested the same.

The most common strategy used by our participants for controlling pain was prescribed drugs and ointments. This is in line with the findings of Gong et al. that reported prescribed and over-the-counter medicines as the most often used strategies by middle-aged and older adults with arthritis (55). A nursing ethnography by Robinson showed that natural remedies, creams and ointments seemed to be perceived as being safer than prescribed medications by older participants (56). It would appear that more research is needed to determine the reasons for not using other effective strategies to relieve pain by nursing home residents.

\section{Conclusions}

Pain is common among residents of Iranian nursing homes and it can affect important life indices such as mood, sleep, communication and activity. This study showed that pain management practices in nursing homes are inadequate and need serious revision. Health policy-makers and geriatric care strategists need to improve the training of care providers in order to manage

\begin{tabular}{|c|c|c|c|c|c|c|c|}
\hline \multirow[t]{2}{*}{ Pain interference } & \multicolumn{2}{|c|}{ Female } & \multicolumn{2}{|c|}{ Male } & \multirow[t]{2}{*}{$\mathbf{z}$} & \multirow{2}{*}{$\begin{array}{c}\text { Mann- } \\
\text { Whitney } \\
\text { U }\end{array}$} & \multirow[t]{2}{*}{$\mathbf{P}$} \\
\hline & $\mathbf{M}$ & SD & $\mathbf{M}$ & SD & & & \\
\hline General activity & 7.02 & 3.10 & 5.32 & 3.05 & -4.840 & 6960.5 & $<0.001$ \\
\hline Mood & 3.84 & 3.41 & 2.80 & 2.77 & -2.409 & 8733.0 & 0.016 \\
\hline Walking & 6.97 & 3.16 & 5.10 & 3.19 & -5.065 & 6798.0 & $<0.001$ \\
\hline Normal work & 7.03 & 3.09 & 5.32 & 3.05 & -4.846 & 6956.5 & $<0.001$ \\
\hline Relations with others & 3.70 & 3.39 & 2.80 & 2.77 & -2.028 & 9007.5 & 0.043 \\
\hline Sleeping & 4.19 & 3.46 & 2.90 & 2.83 & -3.040 & 8278.5 & 0.002 \\
\hline Enjoyment of life & 3.74 & 3.39 & 2.72 & 2.79 & -2.353 & 8777.5 & 0.019 \\
\hline
\end{tabular}


Table 4 Relation of pain and its intensity with demographic variables

\begin{tabular}{lccccc} 
Having pain & \multicolumn{2}{c}{ Chi-Square } & \multicolumn{2}{c}{ Pain intensity } & \multicolumn{2}{c}{ Spearman's Rho Correlations } \\
& $\chi_{2}$ & $\mathbf{P}$ & & $\mathbf{r}$ & \multicolumn{1}{c}{ P } \\
Age & 18.18 & $<0.001$ & Age & 0.210 & $<0.001$ \\
Gender & 15.78 & $<0.001$ & Gender & -0.183 & $<0.001$ \\
Schooling & 19.21 & $<0.001$ & Schooling & -0.133 & $<0.001$ \\
\hline
\end{tabular}

older resdients' pain and help improve their quality of life. Variables such as age, sex and depression can affect pain severity and must be taken into account in pain assessment and management. This study reconfirms the previously mentioned importance of using effective pain evaluation and pain management strategies in nursing homes.

\section{Implications for practice}

Nursing homes personnel needs more training on pain assessment and management in order to lower the levels of pain, frailty and psychological distress among nursing home residents, and revisit pain management strategies to help their residents with the best possible option. Older people also can actively participate in their pain management through self-care training and learning how to use different available means for pain alleviation.

\section{Limitations}

We could not include residents with impaired mental functioning due to ethical considerations and due to the unavailability of their legal or health guardians. This study was implemented only in the metropolitan of Tehran, therefore our findings cannot be generalized to include the whole country and a similar nationwide study is recommended.

\section{Acknowledgements}

We are grateful to Wilco P. Achterberg (Leiden University Medical Center, Netherlands) for reviewing our original manuscript and his valuable comments. The authors would like to thank all the study participants.

Funding: This research was supported by a grant from the University of Social Welfare and Rehabilitation Sciences, Deputy of Research, Islamic Republic of Iran.

Competing interests: None declared.

\section{Caractéristiques des douleurs ressenties par les résidents âgés dans les maisons de retraite iraniennes \\ Résumé}

Contexte: Les douleurs constituent une plainte fréquente chez les personnes vieillissantes, en particulier parmi les résidents âgés des maisons de retraite.

Objectifs : La présente étude a pour objectif principal d'examiner les caractéristiques des douleurs ressenties par les résidents âgés des maisons de retraite à Téhéran (République islamique d'Iran).

Méthodes : Il s'agit d'une étude transversale. L'échantillon se composait de 394 adultes âgés, résidant dans les maisons de retraite de Téhéran. Pour recueillir les données nécessaires, l'échelle du Questionnaire concis sur la douleur et le score du test mental abrégé ont été utilisés.

Résultats : $51 \%$ des femmes et $26 \%$ des hommes ayant participé à l'étude souffraient de douleurs. Les extrémités inférieures et la partie basse du dos étaient les régions les plus fréquemment touchées. La douleur interférait avec l'activité générale $(p=0,001)$, l'humeur $(p=0,016)$, la marche $(p<0,001)$, le travail normal $(p<0,001)$, les relations avec les autres $(p=0,043)$, le sommeil $(p=0,002)$ et la joie de vivre $(p=0,019)$ des résidents âgés et ces effets étaient plus marqués chez les femmes. Des facteurs tels que l'âge, le sexe et le niveau d'instruction étaient en corrélation étroite avec la douleur $(p<0,001)$ et son degré d'intensité $(p<0,001)$.

Conclusions : Les douleurs chroniques sont fréquentes chez les résidents âgés des maisons de retraite et dégradent leur qualité de vie. La présente étude confirme à nouveau l'importance mentionnée précédemment d'utiliser des stratégies efficaces d'évaluation et de prise en charge de la douleur dans les maisons de retraite. 


$$
\begin{aligned}
& \text { خصائص الألم لدى النزلاء كبار السن في دور رعاية المسنين الإير انية } \\
& \text { مهشيد فوروغان، فرحناز محمدي شاهبو لاغي، زهرة جعفري، وحيد راشدي، أكبر بيكلريان } \\
& \text { الخالاصة } \\
& \text { الخلفية: يعد الألم شكوى عامة بين السكان المسنين، لا سيّما بين كبار السن الذين يقطنون دور رعاية المسنين. } \\
& \text { الأهداف: هدفت هذه الدراسة إلى فحص خصائص الألم بين كبار السن في دور رعاية المسنين في مدينة طهر ان، إيران. }
\end{aligned}
$$

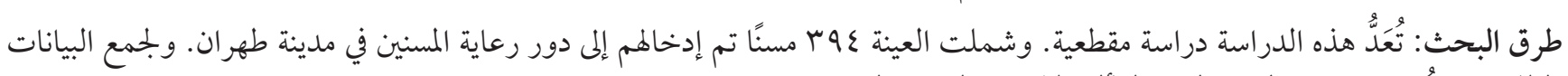

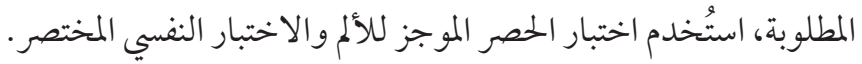

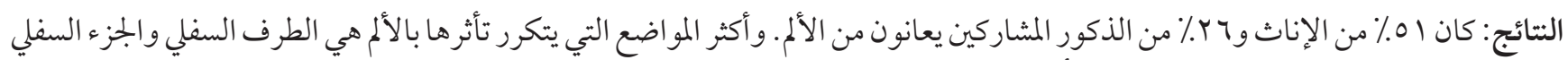

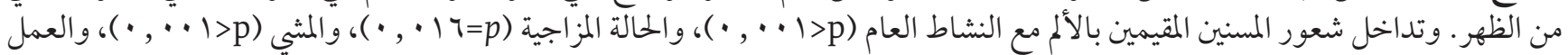

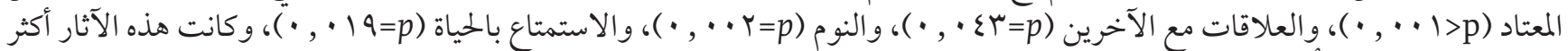

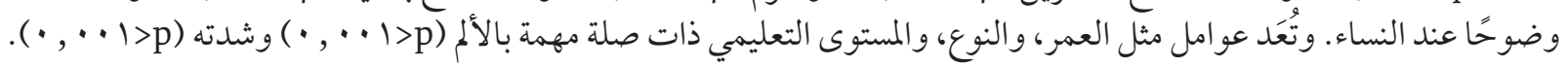

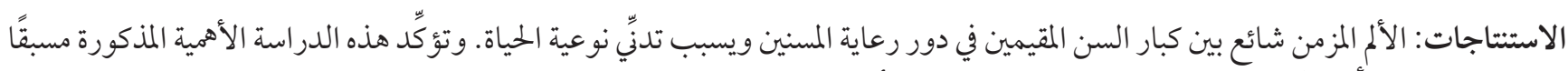

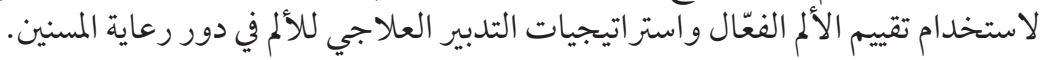

\section{References}

1. Reynolds KS, Hanson LC, DeVellis RF, Henderson M, Steinhauser KE. Disparities in pain management between cognitively intact and cognitively impaired nursing home residents. J Pain Symptom Manage. 2008;35(4):388-96. http://dx.doi.org/10.1016/j. jpainsymman.2008.01.001

2. Reisner L. Pharmacological management of persistent pain in older persons. J Pain. 2011;12(3):S21-9. http://dx.doi.org/10.1016/j. jpain.2011.01.001

3. Lukas A, Mayer B, Fialová D, Topinkova E, Gindin J, Onder G, et al. Pain characteristics and pain control in European nursing homes: cross-sectional and longitudinal results from the Services and Health for Elderly in Long TERm care (SHELTER) study. J Am Med Dir Assoc. 2013;14(6):421-8. http://dx.doi.org/10.1016/j.jamda.2012.12.010

4. Takai Y, Yamamoto-Mitani N, Okamoto Y, Koyama K, Honda A. Literature review of pain prevalence among older residents of nursing homes. Pain Manag Nurs. 2010;11(4):209-23. http://dx.doi.org/10.1016/j.pmn.2010.08.006

5. Horgas AL, Yoon SL, Nichols AL, Marsiske M. The relationship between pain and functional disability in black and white older adults. Res Nurs Health. 2008;31(4):341-54. http://dx.doi.org/10.1002/nur.20270

6. Parker SJ, Jessel S, Richardson JE, Reid MC. Older adults are mobile too! Identifying the barriers and facilitators to older adults' use of mHealth for pain management. BMC Geriatr. 2013;13(1):43. http://dx.doi.org/10.1186/1471-2318-13-43

7. Weiner D, Hanlon J. Pain in nursing home residents: management strategies. Drugs Aging. 2001;18(1):13-29. http://dx.doi. org/10.2165/00002512-200118010-00002

8. Touhy TA, Jett KF, Boscart V, McCleary L. Ebersole and Hess' gerontological nursing and healthy aging: Elsevier Health Sciences; 2014.

9. Pimentel CB, Briesacher BA, Lapane KL. Pharmaceutical pain management among older adults with cancer in nursing homes. UMass Clinical and Translational Science Research: 5th Annual Research. Worcester: University of Massachusetts Medical School; 2014.

10. World Health Organization. Ageing and life course. Geneva: World Health Organization; 2015 (http://www.who.int/ageing/en/).

11. Sandberg J, Lundh U, Nolan M. Placing a spouse in a care home: the importance of keeping. J Clin Nurs. 2001;10(3):406-16.

12. Lukas A, Mayer B, Fialová D, Topinkova E, Gindin J, Onder G, et al. Treatment of pain in European nursing homes: results from the Services and Health for Elderly in Long TERm Care (SHELTER) study. J Am Med Dir Assoc. 2013;14(11):821-31. http://dx.doi. org/10.1016/j.jamda.2013.04.009

13. Zwakhalen SM, Koopmans RT, Geels PJ, Berger MP, Hamers JP. The prevalence of pain in nursing home residents with dementia measured using an observational pain scale. Eur J Pain. 2009;13(1):89-93.

14. Torvik K, Kaasa S, Kirkevold Ø, Rustøen T. Pain and quality of life among residents of Norwegian nursing homes. Pain Manag Nurs. 2010;11(1):35-44. http://dx.doi.org/10.1016/j.pmn.2009.01.001

15. Rashedi V, Asadi-Lari M, Foroughan M, Delbari A, Fadayevatan R. Mental health and pain in older adults: findings from Urban HEART-2. Community Ment Health J. 2017;53(6):719-24. http://dx.doi.org/10.1007/s10597-017-0082-2

16. Statistical Center of Iran. Population and Housing Census Tehran 2017 (http://www.amar.org.ir/Default.aspx?tabid=1190). 
17. Ghazi K, Foroughan M, Hosseini M, Hosseinzadeh S, Askari M. The client satisfaction of delivered services in private nursing homes for elderly: a survey in the provinces of Golestan, Mazandaran, Semnan and Northern Khorasan in 2012. Quarterly Journal of Sabzevar University of Medical Sciences. 2013;20(3):320-30.

18. Welfare Organization of Iran. Instructions for the special requirements and conditions of the rehabilitation and nursing center Tehran 2017. (http://www.behzisti.ir/Portal/file/?251109/tt9.pdf).

19. Fox PL, Raina P, Jadad AR. Prevalence and treatment of pain in older adults in nursing homes and other long-term care institutions: a systematic review. CMAJ. 1999;160(3):329-33.

20. Goucke R. Pain in residential aged care facilities: Management strategies. Australian Pain Society; 2005.

21. Horgas A, Miller L. Pain assessment in people with dementia. Am J Nurs. 2008;108(7):62-70. http://dx.doi.org/10.1097/01. NAJ.0000325648.01797.fc

22. Tse M, Lai C, Lui J, Kwong E, Yeung S. Frailty, pain and psychological variables among older adults living in Hong Kong nursing homes: can we do better to address multimorbidities? J Psychiatr Ment Health Nurs. 2016;23(5):303-11. http://dx.doi.org/10.1111/ jpm.12303

23. Nygaard HA, Jarland M. Are nursing home patients with dementia diagnosis at increased risk for inadequate pain treatment? Int J Geriatr Psychiatry. 2005;20(8):730-7. http://dx.doi.org/10.1002/gps.1350

24. Boerlage AA, Dijk M, Stronks DL, Wit R, Rijt CC. Pain prevalence and characteristics in three Dutch residential homes. Eur J Pain. 2008;12(7):910-6. http://dx.doi.org/10.1016/j.ejpain.2007.12.014

25. Harmon J, Summons P, Maslin-Prothero S, Higgins I. Provision of pain comfort care for the older hospitalised person: An ethnographic study of nursing clinical pain management practices. Australian Nursing and Midwifery Conference2015. p. 78.

26. Asghari A, Ghaderi N, Ashory A. The prevalence of pain among residents of nursing homes and the impact of pain on their mood and quality of life. Arch Iran Med. 2006;9(4):368-73.

27. Baker T. Social and cultural variables: Individual differences in chronic pain and disease in older blacks: The role of psychosocial factors. J Pain. 2004;5(3):S104. http://dx.doi.org/10.1016/j.jpain.2004.02.385

28. Bakhtiyari F, Foroughan M, Fakhrzadeh H, Nazari N, Najafi B, Alizadeh M, et al. Validation of the Persian Version of Abbreviated Mental Test (Amt) in elderly Residents of Kahrizak Charity Foundation. Iranian Journal of Diabetes and Lipid Disorders. 2014;13(6):487-94.

29. Cleeland C, Ryan K. Pain assessment: global use of the Brief Pain Inventory. Ann Acad Med Singapore. 1994;23(2):129-38.

30. Tsai Y-F, Tsai H-H, Lai Y-H, Chu T-L. Pain prevalence, experiences and management strategies among the elderly in Taiwanese nursing homes. J Pain Symptom Manage. 2004;28(6):579-84. http://dx.doi.org/10.1016/j.jpainsymman.2004.03.007

31. Keller S, Bann CM, Dodd SL, Schein J, Mendoza TR, Cleeland CS. Validity of the brief pain inventory for use in documenting the outcomes of patients with noncancer pain. Clin J Pain. 2004;20(5):309-18. http://dx.doi.org/10.1097/00002508-200409000-00005

32. Mirzamani S, Sadidi A, Salimi S, Besharat M. Validation of the persian version of the brief pain inventory. Acta Med Iran. 2005;43(6):425-8.

33. Hodkinson H. Evaluation of a mental test score for assessment of mental impairment in the elderly. Age Ageing. 1972;1(4):233-8. http://dx.doi.org/10.1093/ageing/1.4.233

34. Swain DG, O'Brien AG, Nightingale PG. Cognitive assessment in elderly patients admitted to hospital: the relationship between the shortened version of the Abbreviated Mental Test and the Abbreviated Mental Test and Mini-Mental State Examination. Clin Rehabil. 2000;14(6):608-10. http://dx.doi.org/10.1191/0269215500cr368oa

35. Foroughan M, Jafari Z, Shirinbayan P, Farahani ZG, Rahgozar M, editors. Validation of Abbreviated Mental Test Score and its correlation with Mini Mental State Examination in elderly population of Iran. Third Congress of Aging Issues in Iran and Other Countries; 2008; Tehran.

36. Foroughan M, Wahlund LO, Jafari Z, Rahgozar M, Farahani IG, Rashedi V. Validity and reliability of Abbreviated Mental Test Score (AMTS) among older Iranian. Psychogeriatrics. 2017;17(6):460-5. http://dx.doi.org/10.1111/psyg.12276

37. Stubbs B, Eggermont L, Patchay S, Schofield P. Older adults with chronic musculoskeletal pain are at increased risk of recurrent falls and the brief pain inventory could help identify those most at risk. Geriatr Gerontol Int. 2015 Jul;15(7):881-8. http://dx.doi. org/10.1111/ggi.12357

38. Cadogan MP, Edelen MO, Lorenz KA, Jones M, Yosef J, Hascall T, et al. The relationship of reported pain severity to perceived effect on function of nursing home residents. J Gerontol A Biol Sci Med Sci. 2008;63(9):969-73. http://dx.doi.org/10.1093/gerona/63.9.969

39. Achterberg WP, Pot AM, Scherder EJ, Ribbe MW. Pain in the nursing home: assessment and treatment on different types of care wards. J Pain Symptom Manage. 2007;34(5):480-7. http://dx.doi.org/10.1016/j.jpainsymman.2006.12.017

40. Tse M, Leung R, Ho S. Pain and psychological well-being of older persons living in nursing homes: an exploratory study in planning patient-centred intervention. J Adv Nurs. 2012;68(2):312-21.

41. Tse MMY, Sin Vong SK, Ho SSK. The effectiveness of an integrated pain management program for older persons and staff in nursing homes. Arch Gerontol Geriatr. 2012;54(2):e203-12. http://dx.doi.org/10.1016/j.archger.2011.04.015

42. Leong IY-O, Nuo TH. Prevalence of pain in nursing home residents with different cognitive and communicative abilities. Clin J 
Pain. 2007;23(2):119-27. http://dx.doi.org/10.1097/01.ajp.0000210951.01503.3b

43. Sawyer P, Lillis JP, Bodner EV, Allman RM. Substantial daily pain among nursing home residents. J Am Med Dir Assoc. 2007;8(3):158-65. http://dx.doi.org/10.1016/j.jamda.2006.12.030

44. McClean WJ, Higginbotham NH. Prevalence of pain among nursing home residents in rural New South Wales. Med J Aust. 2002;177(1):17-20.

45. Torvik K, Kaasa S, Kirkevold Ø, Rustøen T. Pain in patients living in Norwegian nursing homes. Palliat Med. 2009;23(1):8-16. http://dx.doi.org/10.1177/0269216308098800

46. Williams JS, Ng N, Peltzer K, Yawson A, Biritwum R, Maximova T, et al. Risk Factors and Disability Associated with Low Back Pain in Older Adults in Low-and Middle-Income Countries. Results from the WHO Study on Global AGEing and Adult Health (SAGE). PLoS One. 2015;10(6):e0127880. http://dx.doi.org/10.1371/journal.pone.0127880

47. López-Lopez A, González JL, Alonso-Fernández M, Cuidad N, Matías B. Pain and symptoms of depression in older adults living in community and in nursing homes: the role of activity restriction as a potential mediator and moderator. Int Psychogeriatr. 2014;26(10):1679-91. http://dx.doi.org/10.1017/S1041610214000970

48. McDonald DD, Shea M, Fedo J, Rose L, Bacon K, Noble K, et al. Older adult pain communication and the brief pain inventory short form. Pain Manag Nurs. 2008;9(4):154-9. http://dx.doi.org/10.1016/j.pmn.2008.03.001

49. Mobily PR, Herr KA, Clark MK, Wallace RB. An epidemiologic analysis of pain in the elderly the Iowa $65+$ rural health study. J Aging Health. 1994;6(2):139-54. http://dx.doi.org/10.1177/089826439400600201

50. Fries BE, Simon SE, Morris JN, Flodstrom C, Bookstein FL. Pain in US nursing homes validating a pain scale for the Minimum Data Set. Gerontologist. 2001;41(2):173-9.

51. Kim W, Jin YS, Lee CS, Bin S-i, Lee SY, Choi KH. Influence of Knee Pain and Low Back Pain on the Quality of Life in Adults Older Than 50 Years of Age. PM R. 2015;7(9):955-61. http://dx.doi.org/10.1016/j.pmrj.2015.03.002

52. Tse MM, Wan VT, Vong SK. Health-related profile and quality of life among nursing home residents: does pain matter? Pain Manag Nurs. 2013;14(4):e173-84. http://dx.doi.org/10.1016/j.pmn.2011.10.006

53. Hairi NN, Cumming RG, Blyth FM, Naganathan V. Chronic pain, impact of pain and pain severity with physical disability in older people-Is there a gender difference? Maturitas. 2013;74(1):68-73. http://dx.doi.org/10.1016/j.maturitas.2012.10.001

54. Willman A, Petzäll K, Östberg AL, Hall-Lord ML. The psycho-social dimension of pain and health-related quality of life in the oldest old. Scand J Caring Sci. 2013;27(3):534-40.

55. Gong G, Li J, Li X, Mao J. Pain experiences and self-management strategies among middle-aged and older adults with arthritis. J Clin Nurs. 2013;22(13-14):1857-69.

56. Robinson SG. The experiences of Black American older adults managing pain: A nursing ethnography. Wayne State University; 2015. 